\title{
Identification of Quality Indicators in Teacher Education Program
}

\author{
Saghir Ahmad \\ PhD Scholar, Institute of Education and Research, University of the Punjab, Lahore Pakistan \\ Dr. Ayesha Batool \\ Lecturer Institute of Education and Research, University of the Punjab, Lahore Pakistan
}

\begin{abstract}
The present research aimed to investigate the perception of teachers' quality indicators in teacher education programs. The objectives of the study were to explore the perception of teachers regarding quality indicators in teacher education program, find out the difference of opinion about principles of quality indicators among university teachers regarding their teaching experience. Research was quantitative in nature survey research design was used in this study. Population of this study was all university teachers teaching in teacher education programs in universities of Lahore. Sample was drawn by using simple random sampling. Questionnaire was used for the collection of data. Descriptive and inferential statistics were applied for the analysis of data. The major findings of the study showed that the positive perception of teachers' quality indicators in teacher education programs. Teachers were satisfied from the quality indicators of teacher education program.
\end{abstract}

Key words: Quality Indicator, and Teachers education program.

DOI: $10.7176 / \mathrm{JEP} / 11-1-02$

Publication date: January $31^{\text {st }} 2020$

\section{Introduction}

Quality education is one of the most attractive objectives all over the globe. One of the six objectives, illustrated by the World Education is identified with the improvement of "all parts of value based and quality education" so as to accomplish the recognized learning results (UNESCO, 2000). As different variables including educational program, conveyance of substance, learning condition, supervision, and organization of scholarly offices add to the nature of training, the focal significance of the instructor cannot be denied. The ability and eagerness of instructors decide the statures to which an instructive framework can rise (Iqbal, 1996). Paliakoff and Schwartzbeck (2001), see that nature of instructors is the most basic part of teaching and that it directly affects student learning. Literature recommends that quality of instructors relies upon instructive capabilities of educators and nature of pre-administration and in-administration instructor training (Aga Khan Foundation, 1998; Sharma, 1993). Instructor training in this way accepts extraordinary significance in accomplishing the objective of quality education.

In Pakistan, the quality of educator instruction has been addressed and censured every now and then by the concerned bodies. So as to satisfy the developing needs of educators at different levels, the instructor training framework has experienced critical quantitative extension, yet the quality of educators' training has been ignored and bargained. Remarking on the present condition of educator training in Pakistan, the National Education Policy: 1998-2010 detects: "The qualitative component of instructor training program has gotten negligible consideration bringing about large scale manufacturing of educators with shallow comprehension of both the substance and system of instruction" (Government of Pakistan, 1998, p.47). An ongoing report distributed by UNESCO about instructor training in Pakistan calls attention to that "nonattendance of value must be handled earnestly in a setting where educator student collaborations are interceded by a strong administration, just as by an empowering arrangement condition" (UNESCO, 2008, p.12). The assessment of current condition of educator instruction quality is urgently required so as to change instructor training segment in Pakistan.

Quality factors are "conventional proclamations made so that they guarantee exhaustive inclusion of the most applicable areas of the quality of instructor training foundation" (National Assessment and Accreditation Council [NAAC], 2007, p.3). Yackulic and Noonan (2001) hold that factors in instructor training reflect the significant parts of instructor training program. Dimensions may play out major roles, for example, portraying current circumstance, evaluating pre-decided targets, giving nonstop input about progression towards accomplishment of targets, what's more, recognizing factors that added to results accomplishment (European Commission, 2001). Chande (2006) accepts that performance factors might be of three sorts: quantitative, story (subjective) and mix of both.

It is hard to characterize quality of education absolutely chiefly due to complex nature of educating learning procedure and enormous number of partners associated with tutoring (Mirza, 2003). Different researchers have distinguished various determinants of training quality. Cheng and Cheung (1997) characterize quality of education as a lot of components containing information, procedure and yield of instruction framework. In light of designing 
model of instruction, Adams' (1993) system of value comprises of establishment' notoriety, assets/input, process, content, yields/results, and worth included. As indicated by Santos (2007), a conventional school quality model is described by test marks and different data sources including learner family contextual, school attributes, instructor attributes and student's natural capacity. The factors of education quality distinguished by Thaung (2008) incorporate students, educators, content, instructing learning forms, learning situations, and results. Actually, the estimation of model is yet to be talked about and broke down in the scholastic writing. Another critical model of quality of education has been given by UNICEF (2000) which includes five measurements for example quality students, quality learning situations, quality substance, quality procedures, and quality results. Memon (2003) contends that this structure seems, by all accounts, to be progressively feasible and important if explicit criteria are charted to evaluate the quality of education.

Quality in existing instructor training projects is right now being bantered in numerous nations and at numerous levels (Hoban, 2004). Like quality of education, quality in educator training cannot be effectively characterized as there are different perspectives on what compelling instructor training projects are. Various originations about the quality of educator readiness are reflected in scope of changes being attempted in different nations (Calderhead, 2001). There are a few normal issues that might be markers of low nature of educator training programs over the globe. Tom (1997) has distinguished ten issues that are tricky in numerous traditional educator training programs: misty objectives, divided courses which need importance and intelligence, incongruity between courses from various resources, discontinuities between college courses and school practice, low status of instructor teachers even inside a personnel of training, autonomous division structures in resources of instruction that advance an absence of coordinated effort, hazy vocation way of educators and their job in practicum supervision, such a large number of partners associated with instructor training, absence of making arrangements for change procedures, and powerlessness of instructor training to one-off change. Hoban (2004) includes eleventh point, absence of correspondence among institutions.

Truth be told, instructor training in Pakistan is experiencing major issues that hinder its general execution and viability. The basic issues include: absence of subsidizing and assets, inadequately prepared preparing establishments, short preparing period, undue accentuation on quantitative extension, limited extent of educational plan, unevenness among general and expert courses, over-accentuation on theory instead of training no coordination between instruction offices and preparing foundations, insufficient nature of guidance, absence of inadministration preparing of instructor teachers, disappointment in executing valuable changes, obscure destinations, low quality of reading material, damaged examination framework, and absence of supervision and responsibility, research and assessment of educator preparing programs (Aly, 2006; Iqbal, 2000). So as to change instructor training part in Pakistan, there is a desperate need to assess the viability of existing educator preparing programs.

\section{Significance of Study}

As the teacher training play and important role in enhancing the quality of teacher so teacher training is very important for teacher to meet the current and futures need of teaching. It is important to bring quality in the educational programs of teachers. This study was focused on identifying the quality indicators in teacher education programs. This study is significant that it generated primary data about quality assurance in teacher education. The findings of this study have implications for HEC, Accreditation Council for Teacher Education and TEIs management for highlighting the important aspects which may be focused for quality improvement in teacher education programs. The suggested quality indicators may also be used for assessing quality of the academic program at TEIs and other institutions of higher education.

\section{Research Objectives}

The objectives of the study were to:

1. Explore the perceptions of teachers regarding quality indicators in teacher education program.

2. Find out the difference between perceptions of lecturer and assistant professor regarding quality indicators in teacher education program.

\section{Research Methodology}

The research was quantitative and survey in nature. The population of the study was comprised of all the teachers working in universities of Lahore. Further only those public universities were taken in which subject of Education is being taught. There are three general public universities in Lahore i.e. University of the Punjab, University of Education and Lahore college for women university. The sample of the study drawn from the target population. There are total 108 teachers were responded. Simple random technique used for the selection of sample. The selfdeveloped questionnaire used by the researchers after reviewing literature. The questionnaire was developed for the teachers' opinion on the Quality indicators rated most important by teachers. Items were constructed on five point Likert scale for this purpose. Validity of questionnaire was ensured through expert opinion. Reliability was 
measured by Cronbach's Alpha.

Table 1

Reliability Statistics

$\begin{array}{cc}\text { Cronbach's Alpha } & \text { No. of Items } \\ .785 & 25\end{array}$

It is indicated that scale has internal consistency, with the Cronbach's Alpha coefficient .785. The researchers personally visited the each institution. The teachers were approached in their concerned classes and department. The confidentiality of data was ensured by taking the consent of respondents. The collected data were analyzed through descriptive and inferential statistics.

\section{Data Analysis}

The detail of data analysis is given below.

Table 2

Descriptive Analysis of statements about "Professional development" of quality indicators in teacher education programs

\begin{tabular}{llc}
\hline Statements & $M$ & $S D$ \\
\hline Professional development is part of improvement plan & 3.92 & .96 \\
practice new skills & 3.85 & .91 \\
Work together. & 3.73 & .92 \\
understanding of the subjects & 3.82 & .94 \\
Focus on discussion & 3.92 & .77 \\
\hline
\end{tabular}

It is indicated mean of the statements about quality indicators in teacher education programs presents that promoted by the university level of the educational institutions is ranging from $\mathrm{M}=(3.73$ to 3.92$), \mathrm{SD}=(.77$ to .96$)$ which including Mean of the scale. It is concluded that majority of the participants are satisfied. So, they are agreed about factor professional development.

Table 3

Descriptive Analysis of statements about "Teaching instructions" of quality indicators in teacher education programs

\begin{tabular}{lcc}
\hline Statements & $M$ & $S D$ \\
\hline use of technology & 3.75 & .75 \\
assess student learning needs & 3.57 & 1.00 \\
Improve student performance. & 3.68 & .95 \\
use different strategies & 3.67 & 1.00 \\
Improve instruction by observations and feedback & 3.74 & .98 \\
\hline
\end{tabular}

It is indicated mean of the statements about quality indicators in teacher education programs presents that promoted by the university level of the educational institutions is ranging from $\mathrm{M}=(3.57$ to 3.75$), \mathrm{SD}=(.75$ to 1.00) which including Mean of the scale. It is concluded that majority of the participants are satisfied. So, they are agreed about factor teaching instructions.

Table 4

Descriptive Analysis of statements about "Developing Knowledge" of quality indicators in teacher education programs

\begin{tabular}{lcc}
\hline Statements & $M$ & $S D$ \\
\hline Instructional and assessment meet the needs of learners. & 3.59 & .95 \\
Use research-based instructional strategies. & 3.72 & .96 \\
Prior knowledge and experience are used to design staff development & 3.72 & 1.01 \\
professional development promotes understanding & 3.87 & .84 \\
Teaching and learning goals depend on staff ability & 3.85 & .98 \\
\hline
\end{tabular}

Teaching and learning goals depend on staff ability

It is indicated mean of the statements about quality indicators in teacher education programs presents that promoted by the university level of the educational institutions is ranging from $\mathrm{M}=(3.59$ to 3.87$), \mathrm{SD}=(.84$ to 1.01$)$ which including Mean of the scale. It is concluded that majority of the participants are satisfied. So, they are agreed about factor developing knowledge. 
Table 5

Descriptive Analysis of statements about "Learning Environment" of quality indicators in teacher education programs

\begin{tabular}{lcc}
\hline Statements & $M$ & $S D$ \\
\hline Observe classroom to improve teaching. & 3.60 & 1.08 \\
Opportunities to work with experienced staff & 3.74 & .94 \\
Creativity & 3.68 & .93 \\
Discuss professional experience. & 3.73 & .93 \\
Leaders encouragement & 3.66 & 1.03 \\
\hline
\end{tabular}

It is indicated mean of the statements about quality indicators in teacher education programs presents that promoted by the university level of the educational institutions is ranging from $\mathrm{M}=(3.60$ to 3.74$), \mathrm{SD}=(.93$ to 1.08$)$ and total $(\mathrm{M}=3.68, \mathrm{SD}=.66)$ which including Mean of the scale. It is concluded that majority of the participants are satisfied. So, they are agreed about factor learning environment.

Table 6

Descriptive Analysis of statements about "Relationship" of quality indicators in teacher education programs

\begin{tabular}{lcc}
\hline Statements & $M$ & $S D$ \\
\hline positive relationships & 3.88 & .98 \\
Use classroom performance to assess the success & 3.78 & .91 \\
learn effective assessment techniques & 3.71 & .94 \\
Training & 3.65 & .91 \\
improve teaching standard & 3.76 & .88 \\
\hline
\end{tabular}

It is indicated mean of the statements about quality indicators in teacher education programs presents that promoted by the university level of the educational institutions is ranging from $\mathrm{M}=(3.65$ to 3.88$), \mathrm{SD}=(.88$ to.98) which including Mean of the scale. It is concluded that majority of the participants are satisfied. So, they are agreed about factor relationship.

Table 7

Independent Sample t-test to find out the difference of opinion between lecturer and Assistant professor for the quality indicators about professional development

\begin{tabular}{lcccccc} 
Statements & \multicolumn{2}{c}{ Lecturer } & \multicolumn{2}{c}{ Assistant Professor } & \multirow{2}{*}{ Sig } \\
\cline { 2 - 5 } & $M$ & $S D$ & $M$ & SD & & \\
\hline Professional development is part of improvement plan & 4.07 & .86 & 3.44 & 1.12 & 2.59 & $.01^{*}$ \\
practice new skills & 3.95 & .90 & 3.52 & .91 & 2.07 & $.04^{*}$ \\
Work together. & 3.83 & .86 & 3.48 & 1.08 & 1.48 & .14 \\
understanding of the subjects & 3.89 & .96 & 3.68 & .94 & .96 & .33 \\
Focus on discussion & 3.95 & .77 & 3.92 & .75 & .18 & .85 \\
\hline
\end{tabular}

It is concluded that they have significance difference regarding Professional development is part of my university improvement plan. They have significance difference regarding Teachers have opportunities to practice new skills gained during staff development. They have not significance difference regarding the faculty learns about effective ways to work together. Teachers are provided opportunities to gain deep understanding of the subjects they teach. It is concluded that they have significance difference regarding factor professional development.

Table 8

Independent Sample t-test to find out the difference of opinion between lecturer and Assistant professor for the quality indicators in teacher education programs

\begin{tabular}{|c|c|c|c|c|c|c|}
\hline \multirow[t]{2}{*}{ Statements } & \multicolumn{2}{|c|}{ Lecturer } & \multicolumn{2}{|c|}{ Assistant Professor } & \multirow[t]{2}{*}{$t$} & \multirow[t]{2}{*}{ Sig } \\
\hline & $M$ & $S D$ & $M$ & $S D$ & & \\
\hline use of technology & 3.80 & .74 & 3.64 & .63 & .01 & .99 \\
\hline assess student learning needs & 3.60 & .99 & 3.60 & .95 & 1.18 & .23 \\
\hline Improve student performance. & 3.73 & .89 & 3.48 & 1.08 & 3.46 & $.00 *$ \\
\hline use different strategies & 3.85 & 1.0 & 3.08 & .90 & 1.88 & .06 \\
\hline Improve instruction by observations and feedback & 3.84 & .90 & 3.44 & 1.04 & 1.43 & .15 \\
\hline
\end{tabular}

It is concluded that they have not significance difference regarding teachers' have opportunities to learn how to use technology to enhance instructions. They have not significance difference regarding teachers at my university learn how to use data to assess to student learning needs. It seems that they have significance difference regarding we make decisions about professional development based on research that shows evidence to improved student performance. It is concluded that they have significance difference regarding factor teaching instructions. 
Table 9

Independent Sample t-test to find out the difference of opinion between lecturer and Assistant professor for the quality indicators of developing knowledge

\begin{tabular}{|c|c|c|c|c|}
\hline \multirow[t]{2}{*}{ Statements } & \multicolumn{3}{|c|}{ Lecturer Assistant Professor } & \multirow[t]{2}{*}{$t \quad$ Sig } \\
\hline & $M S D$ & $M$ & $S D$ & \\
\hline Instructional and assessment meet the needs of learner & 3.67 .95 & 3.36 & .99 & 1.43 .15 \\
\hline Use research-based instructional strategies. & 3.79 .93 & 3.64 & .95 & .72 .47 \\
\hline Prior knowledge and experience are used to design staff development & 3.85 .96 & 3.36 & 1.11 & $2.17 .03 *$ \\
\hline professional development promotes understanding & 4.02 .79 & 3.52 & .87 & $2.71 .00 *$ \\
\hline staff ability & 3.91 .99 & 3.56 & 1.00 & 1.57 .11 \\
\hline
\end{tabular}

It is concluded that they have not significance difference regarding instructional and assessment to meet the needs of divers' learners. They have significance difference regarding teacher prior knowledge and experience is taken into consideration when designing staff development at our university. It is concluded that they have significance difference regarding our professional development promotes deep understanding about the content we teach in class. They have significance difference regarding factor developing knowledge.

Table 10

Independent Sample t-test to find out the difference of opinion between lecturer and Assistant professor for the quality indicators of learning environment

\begin{tabular}{lcccccc} 
Statements & \multicolumn{2}{c}{ Lecturer } & \multicolumn{2}{c}{ Assistant Professor } & \multirow{2}{*}{$t$} & \multirow{2}{*}{ Sig } \\
\cline { 2 - 5 } & $M$ & $S D$ & $M$ & $S D$ & & \\
\hline Observe classroom to improve teaching. & 3.61 & 1.1 & 3.64 & 1.15 & -.10 & .91 \\
Opportunities to work with experienced staff & 3.84 & .93 & 3.56 & .96 & 1.32 & .18 \\
Creativity & 3.67 & .91 & 3.64 & 1.07 & .16 & .87 \\
Discuss professional experience. & 3.75 & .95 & 3.48 & .91 & 1.28 & .20 \\
Leaders encouragement & 3.79 & .94 & 3.12 & 1.23 & 2.90 & $.00^{*}$ \\
\hline
\end{tabular}

It is concluded that they have not significance difference regarding we observe each other's classroom instruction as one way to improve our teaching. They have not significance difference regarding creative ways to expand human and material resources. It is concluded that they have significance difference regarding my university leaders encourage sharing responsibility to achieve university goals.

Table 11

Independent Sample t-test to find out the difference of opinion between lecturer and Assistant professor for the quality indicators about relationship

\begin{tabular}{|c|c|c|c|c|c|c|}
\hline \multirow[t]{2}{*}{ Statements } & \multicolumn{2}{|c|}{ Lecturer } & \multicolumn{2}{|c|}{ Assistant Professor } & \multirow[t]{2}{*}{$t$} & \multirow[t]{2}{*}{ Sig } \\
\hline & $M$ & $S D$ & $M$ & $S D$ & & \\
\hline positive relationships & 3.93 & .96 & 3.60 & 1.04 & 1.51 & .13 \\
\hline Use classroom performance to assess the success & 3.87 & .84 & 3.44 & 1.15 & 1.76 & .08 \\
\hline learn effective assessment techniques & 3.71 & .94 & 3.72 & 1.02 & -.04 & .96 \\
\hline Training & 3.68 & .92 & 3.72 & .89 & -.15 & .87 \\
\hline improve teaching standard & 3.83 & .86 & 3.64 & .95 & .94 & .34 \\
\hline
\end{tabular}

It is concluded that they have not significance difference regarding we are focused on creating positive relationships between teachers and students. They have no significance difference regarding my university professional development helps me to learn about effective student's assessment techniques and administrators engage teachers in conversations about instruction and student learning to improve teaching standard and relationship.

\section{Conclusion}

The present research aimed to investigate the perception of teachers' quality indicators in teacher education programs. It was concluded that scale has high internal consistency. Majority of the participants were agreed about factor professional development, teaching instructions, developing knowledge, learning environment and relationship. It is concluded that they have significance difference regarding Professional development is part of my university improvement plan. They have significance difference regarding Teachers have opportunities to practice new skills gained during staff development. They have not significance difference regarding the faculty learns about effective ways to work together. Teachers are provided opportunities to gain deep understanding of the subjects they teach. It is concluded that they have significance difference regarding factor professional development. It is concluded that they have not significance difference regarding teachers' have opportunities to learn how to use technology to enhance instructions. They have not significance difference regarding teachers at my university learn how to use data to assess to student learning needs. It seems that they have significance difference regarding we make decisions about professional development based on research that shows evidence to 
improved student performance. It is concluded that they have significance difference regarding factor teaching instructions. It is concluded that they have not significance difference regarding instructional and assessment to meet the needs of divers' learners. They have significance difference regarding teacher prior knowledge and experience is taken into consideration when designing staff development at our university. It is concluded that they have significance difference regarding our professional development promotes deep understanding about the content we teach in class. They have significance difference regarding factor developing knowledge. It is concluded that they have not significance difference regarding we are focused on creating positive relationships between teachers and students. They have no significance difference regarding my university professional development helps me to learn about effective student's assessment techniques and administrators engage teachers in conversations about instruction and student learning to improve teaching standard and relationship.

\section{Recommendations}

On the basis of conclusion, following recommendations made.

1. Since the concept of quality indicators is relatively new in under- developing countries like ours, so a number of programs, seminars, workshops and conferences for the purpose of awareness and importance of quality indicators be planned at district, division and provincial level.

2. For the purpose of comparison similar research studies should be conducted to gain information about quality indicators of teachers in public and private sector. This will not only be helpful in bringing qualitative changes in teaching but will also create an atmosphere of competition between public and private sector institutions.

3. Identical research studies at primary, secondary and treasury level teachers are recommended in future so that teachers at all level may be prepared keeping in consideration the importance of quality indicators.

4. For more understanding of quality indicators a number of training programs specially for teachers working in rural areas and also for the female teachers should be arranged at tehsil and district level so that more and more teachers may participate and there professional competence through emotional intelligence may be enhanced.

5. Government, policy makers and curriculum developers should give due considerations to the concept of instructional behavior so that the students and teacher may get more and more benefits of teaching learning process in the form of success.

\section{References}

Adams, D. (1993). Defining education quality. In Improving educational quality project. Arlington, Institute for International Research.

Aga Khan Foundation. (1998). Putting the child first: Teacher education for quality learning and school improvement. Social Policy Forum. Pakistan-Canada Social Institutions Development Programme.

Aly, J. H. (2006). Education in Pakistan: A white paper. Document to debate and finalize the national education policy. Islamabad: Government of Pakistan.

Calderhead, J. (2001). International experiences of teaching reform. In V. Richardson (Ed.) Handbook of research on teaching (4th Ed.). Washington, DC: American Educational Research Association

Chande, S. U. (2006). Performance indicators of an institute of higher education (13-20). In Proceedings of $1 \mathrm{st}$ international conference on assessing quality in higher education, 11-13 December, 2006, Lahore-Pakistan.

Cheng, Y., \& Cheung, W. (1997). Multi-model of education quality and multi levels of self-management in schools. Educational Management and Administration, 25(4), 26-37.

Dilshad, R. M. (2010). Assessing Quality of Teacher Education: A Student Perspective. Pakistan Journal of social sciences (PJSS), 30(1).

European Commission. (2001). European report on quality of school education. Luxembourg: DirectorateGeneral of Education and Culture.

Government of Pakistan. (1998). National policy of education: 1998-2010. Islamabad: Ministry of Education.

Hoban, G. F. (2004). Seeking quality in teacher education design: A four-dimensional approach. Australian Journal of Education, 48 (2), 117-133.

Iqbal, M. Z. (2000). Teacher education. In Syed Jawad Ahmad (Ed.), Proceedings of national seminar on education: The dream and reality (June 13-14 2000). Islamabad: Ministry of Education, Government of Pakistan.

Iqbal, Z. (1996). Teacher training: The Islamic perceptive. Islamabad: Institute of Policy Studies.

Memon, M. (2003). The quality of education in Pakistan: A national policies perspective. A paper presented in the conference on The Research and Policy Dialogue on Achieving Quality in Education held in Lahore on March 4-5, 2003.

Mirza, M. S. (2003). Quality of primary education in Pakistan. Islamabad: UNESCO. 
National Assessment and Accreditation Council. (2007). Quality indicators for teacher education. Banglore: Commonwealth of Learning.

Paliakoff, A., \& Schwartzbeck, T. D. (Eds). (2001). Eye of the storm: Promising practices for improving instruction. Washington D.C.: CBE.

Santos, M. E. (2007). Quality education in Argentina: Determinants and distribution using PISA test scores. Retrieved from siteresources.worldbank.org/EDUCATION/.../SessionII_MariaEmmaSantos4.pdf

Sharma, M. (1993). Teacher education: The quest for quality. In E. Thomas et al., Professional development of teachers: Policy and practice in initial teacher training. London: Commonwealth Secretariat.

Thaung, N. N. (2008). Quality indicator. A paper presented in the Capacity Building Workshop on Monitoring and Evaluating Progress in Education in the Pacific in Nadi, FIJI on 27-31 October 2008.

Tom, A. R. (1997). Redesigning teacher education. Albany, NY: State University of New York.

UNESCO (2000). World education forum: Dakar framework for action 2000. Paris: UNESCO.

UNESCO (2008). Status of teachers in Pakistan 2008. Lahore: UNESCO/USAID/ITA

Yackulic, R. A., \& Noonan, B.W. (2001). Quality indicators for teacher training in Canada. Paper prepared for The 2001 Pan-Canadian Education Research Agenda Symposium May 22-23, 2001, Lavel University Quebec City. 